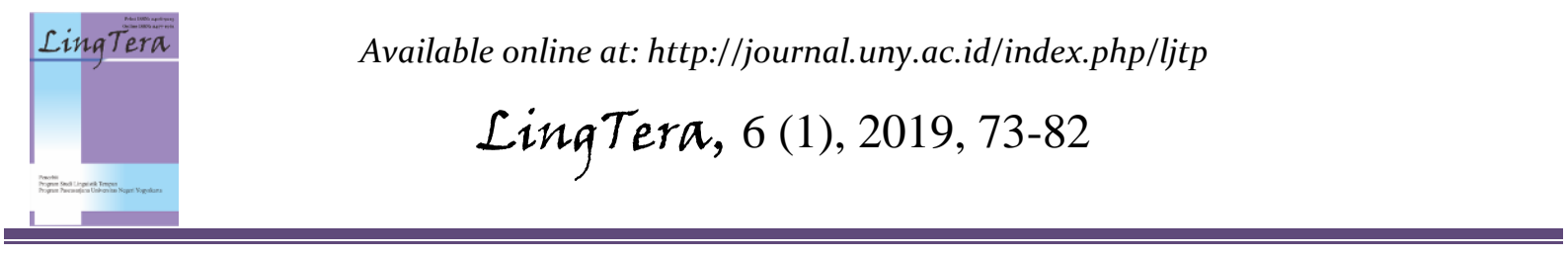

\title{
Gender and politeness on Instagram
}

\author{
Arini Dwi Sholikhatin, Rohmani Nur Indah * \\ Faculty of Humanities, Universitas Islam Negeri Maulana Malik Ibrahim Malang \\ Jalan Gajayana No.50, Dinoyo, Kec. Lowokwaru, Kota Malang, Jawa Timur 65144, Indonesia \\ * Corresponding Author. E-mail: indah@bsi.uin-malang.ac.id
}

Received: 12 July 2019; Revision: 9 September 2019; Accepted: 16 September 2019

\begin{abstract}
This study is to identify the positive politeness of responses from male and female in responding to Bill Gates' caption on Instagram. It used a descriptive qualitative approach to explain the kind of positive politeness strategy applied. The data were in the form of positive utterances written by males and females in column comments in Bill Gates Instagram account analysed using Brown and Levinson's theory of politeness. The data were collected in February 2019, involving positive comments on Instagram. The results showed not all of the fifteen strategies of positive politeness appear. The strategy of noticing or attending to one's interests and needs ranked the highest for the category of the most often appearing strategy used by males and females. The male's comments tend to employ the strategy of joking about putting the hearer at ease and strategy of offering, promising. Whereas, the dominant positive politeness strategy used by females are noticing, attending to the hearer's interests, wants, needs, or goods.
\end{abstract}

Keywords: gender, Instagram, pragmatic, positive politeness, politeness strategy

How to Cite: Sholikhatin, A., \& Indah, R. (2019). Gender and politeness on Instagram. LingTera, 6(1), 73-82. doi:https://doi.org/10.21831/lt.v6i1.26058

This is an open-access article under the CC-BY-SA license.

\section{INTRODUCTION}

Politeness is a way to improve speech. It is well expressed as the utilisation of a proper manner indicating respect through language for communication and for creating good relationships among people. The knowledge of politeness also cultivates one's communicative competence (Kurdghelashvili, 2015; Saragih, 2016). In this case, some notions are related to the concept of politeness, such as negative politeness and positive politeness. While negative politeness is used to interfere with the listeners, positive politeness is a strategy that leads the speaker to appeal the common goals. The speech attempts to avoid the hearer's rejection. It aims to achieve solidarity (Brown, Levinson, \& Levinson, 1987). It means applying strategies to achieve the purpose of communication.

Achieving effective communication is an essential part of human life. It is expected that both speakers and listeners can be polite to each other. Being polite does not only involve the understanding of language but also requires factors such as social and cultural values of the community to be taken into account. Maintaining politeness is also needed in communicating through social media. There are many posts uploaded by people to attract the attention of other social media users. It is a form of indirect social interaction; people freely comment on it in the comment section to respond to the post. People show many kinds of responses, whether it is a positive or negative response.

Current studies show various phenomenon of politeness since the data continue to improve updates from everything new. Besides, nowadays, a lot of social media emerge, where we can see the politeness of other people through their writing on social media. One of the most popular social media today is Instagram. It is one of the world's communication tools among people today. This phenomenon is believed to remain as the number of Instagram user increases every day. Not only is Instagram being used as a communication tool yet, but it also helps people share their thoughts and opinions. It is also believed to be an effective platform for political communication (Bossetta, 2018). 


\section{LingTera,6 (1), 2019 - 74}

\section{Arini Dwi Sholikhatin, Rohmani Nur Indah}

People are competing to post things on Instagram every day. Not only ordinary people, ranging from artists, officials, even influential world leaders. Thousands of comments always flood every post uploaded containing self-praise, hashtags, and politeness reflecting new literacies in digital media (Matley, 2018). The comments can be responded positively, although sometimes do not always show the impression of politeness. However, some of the Instagram users also consider the politeness aspect based on the social distance factor (Ammaida \& Muttaqien, 2018).

The topic of politeness is considered as exciting topics for linguistic researchers especially on pragmatics as it deals with language users within their social context and cannot be confined to those aspects of the context grammatically coded (Mey, 2001). It also addresses the context-variable aspects characterising language use, to broaden the scope of traditional linguistic practice (Horn \& Kecskés, 2013). Pragmatics assumes that people usually follow a particular type of cooperative principle when communicating with one another, including how to apply politeness in speech (Paltridge, 2012).

There are many studies investigating politeness strategy, but it applied in different contexts. Research on politeness is significant because some studies show several facts. A study using chi-square test suggests that EFL learners use inexact expressions of politeness in their responses (Gharaghani, Eslami Rasekh, Dabaghi, $\&$ Tohidian, 2011). Since EFL learners believe that norms of social in politeness are universal, L1 pragmatic norms are observable in EFL performances. The other fact is that the results obtained by the current researchers are incontrovertible in the meaning that teaching on politeness and indirectness strategies has a positive effect on the use of language by EFL learners in general, and in particular, on female EFL learners (Harooni \& Pourdana, 2017). Besides, the teaching of politeness speech is also responsible for creating the character of the learners (Duhita \& Zulaeha, 2018) as the practice of politeness is realised during the classroom interaction (Fajaruddin, 2011; Jauhari, 2017).

Also, the other result showed that the address terms of positive politeness in conversation are thanking, apology, praising, obedience, request, suggestion, and disagreement (Kamlasi, 2017). Moreover, the other fact is that the results are ten types of strategies positive politeness found, in animated characters (Pradnyani, Budiarsa, \& Sudana, 2017) as well as the fulfilment of cooperative maxims as the principle of politeness applied in a talk show (Ariputra, Rohmadi, \& Sumarwati, 2018). Another fact is that the findings provide other proof of how the substance of linguistics used to improve comprehension of workplace pragmatics, especially about politeness (De Felice \& Garretson, 2018).

Because politeness is continuing and becoming an actual topic to be discussed from those previous studies, this study considered that politeness is an exciting topic for linguistic researchers. While the discussion concerning negative politeness or impoliteness is more spreading today, especially in the context of cyberbullying (Indrawan, 2018) and expressing hatred to celebrities (Anggriani, 2016), more finding is still needed in terms of exploring positive politeness. Within the context of social media, this study is intended to explore the gender difference. Therefore, this study investigates the differences in how men and women use politeness strategies in responding to captions from one of Bill Gates ' Instagram accounts, who is an influential figure in the world today in the comments column. Not only have millions of followers, but Gates' account also conveys the rich expression of positive politeness in the comments of every single post.

The purpose of this study was to investigate Brown and Levinson's theoretical assumptions about politeness. It was conducted to find out the politeness that is used by the society, especially the utterances that was in a positive comment on one of the influential world leaders' captions on Instagram. Besides that, it investigated gender differences, in this view is politeness that is used by males and females that repressented through their comments in the comment column on Instagram.

\section{METHOD}

This research used the qualitative descriptive approach because the data were in the form of words or sentences. The descriptive involves collecting data for testing or answering questions about the purpose of the research (Gay, Mills, \& Airasian, 2011). This research aims to analyse the politeness that the readers used when commenting on another person's captions. The source of data covers one of the world's most popular social media, Instagram.

The data of this research are the comments taken from Bill Gates' account on Instagram with 2, 5 million followers. The data were the utterances in the comment column among men 


\section{LingTera,6 (1), 2019 - 75}

Arini Dwi Sholikhatin, Rohmani Nur Indah

and women that gave responses to Bill Gates' captions. The writer limited the data by selecting positive comments only from the readers. The comments taken by the writer are one of the latest captions of Bill Gates on February, 21th 2019. The data use equal amounts of comments from both males and females.

The data are analysed by collecting, selecting, and classifying the appropriate utterances with the method and relevant concept, especially the positive politeness theory of Brown and Levinson. The data collection process took the following steps: reading the comments in the Bill Gates account, choosing the comments that included positive comments/responses, carrying out the data with screenshots as a tool, all data are then typed, coded and grouped into the principle of politeness.

The data analysis is, first of all, to answer the research questions. The data are identified and classified by using the following steps. First, the data were analysed using positive politeness strategies based on Brown and Levinson's theory. Second, the analysis consists of the process of classifying the data into two categories, men and women comments. Additionally, the language patterns used by men and women in the comment column are analysed. This process was done to identify the differences that occurred in the comments of different genders. Finally, data were analysed to determine the politeness of gender differences. Afterwards, the researchers interpreted and described the data before presenting the conclusion.

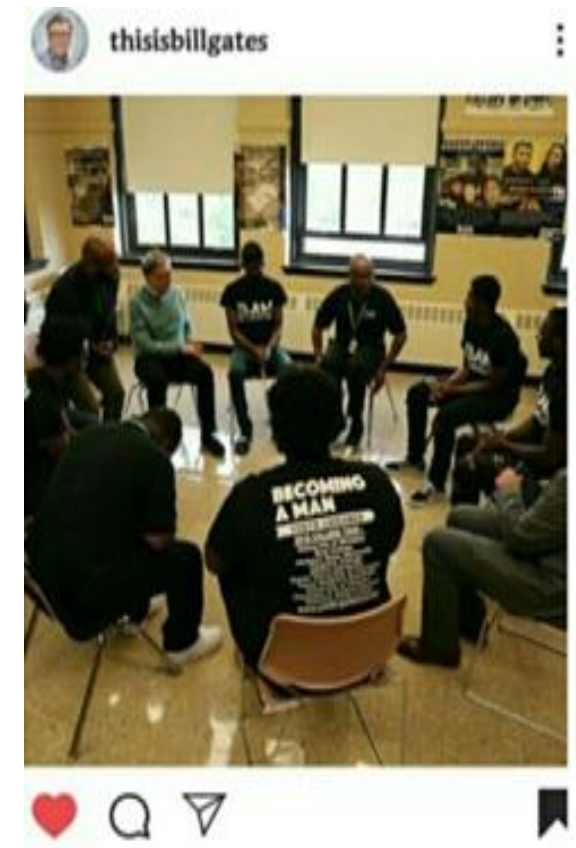

\section{RESULTS AND DISCUSSION}

\section{Results}

The contexts of data were comments as written by the Instagram user in the comment column of Bill Gates' Instagram account (@thisisbillgates). The comments taken are one of the latest captions of Bill Gates on February, 21st 2019. This caption gets 1232 comments and 105.892 likes from the Instagram users.

"One of the most remarkable experiences for me last year was participating in a discussion group with a bunch of teenage boys at a high school in Chicago. Although some of the guys talked about the typical teenage frustrationsa teacher was mistreating them, or they kept dying in a video game-others had tragic stories. One had just watched a family member go to jail. Another spoke about a friend who had been shot. It was inspiring to see these young men working on dealing with their anger much earlier than I did. I was touched by the respect they had for each other and the intimacy they allowed themselves. I left thinking: This is how every classroom in the world should feel."

Men's comments

\section{@liorskaler}

(4 weeks ago, 1 like)

Agreed. We need discussions like these to happen frequently so people can have the support they so desperately need. (PP/24)

\subsection{2 suka}

thisisbillgates One of the most surprising experiences for me last year was participating in a discussion group with a bunch of teenage boys at a high school in Chicago. Although some of the guys talked about typical teenage frustrations-a teacher was treating them unfairly, or they kept dying in a video game-others had tragic stories. One had just watched a family member go to jail. Another spoke about a friend who had been shot. It was inspiring to see these young men working on dealing with their anger much earlier than I did. I was touched by the respect they had for each other and the intimacy they allowed themselves. I left thinking: This is how every classroom in the world should feel.

Lihat semua 1.232 komentar

21 Iebruar + Lhat tevemahan

Figure 1. Bill Gates' Instagram Account 


\section{LingTera,6 (1), 2019 - 76}

\section{Arini Dwi Sholikhatin, Rohmani Nur Indah}

Bill Gates (the hearer) tells about the teenage boy's group discussion sharing their problems and experiences. Then, he (the speaker) tries to save Bill Gates' positive face by seeking an agreement from the hearer's statement. The speaker expresses his agreement by saying, “Agreed..." By saying this agreement, he shows his cooperation with Bill Gates' statement. It indicates that the utterance uses the strategy of seeking an agreement.

@self_taught_android_developer

(4 weeks ago, 1 like)

@thisisbillgates one day I will become better than you sir (PP/25)

The speaker conveys to Bill Gates (the hearer) that he can be a better person than him. The speaker stresses his cooperation by promising to the hearer that he will become better. This expression can reduce the imposition when the speaker is promising with the hearer. Thus, it fulfilled the hearer's positive face by being appreciated. So, the utterance includes positive politeness that used the strategy of offering, promising

@kkhaliff

(3 weeks ago)

Aye Bill, I see you!! That lit. Hope it's from the heart. (PP/31)

An informal word is chosen to show his feeling. It does not mean that he is closed to Bill Gates (the hearer), but it refers to the identity marker. The identity markers are "Bill" as a familiar nickname and "Aye" as another address form. The speaker uses these words to reduce the threat as he is looking at the hearer every time. Then the hearer's positive face is saved as being treated as a similar group member. It means that there are no differences between them. Then, it reflects in-group identity markers.

@ richard_kinsley_

(4 weeks ago, 146 likes)

Mr. William Gates. I get it. You are richer than I am. Pfpfpf... (PP/3)

In this utterance, the speaker amused the hearer (Bill) through a joke about reality. That Bill Gates richer than him is an actual reality, but he makes it a joke to show the solidarity to the hearer, making the hearer feel relieved. It means the speaker tries to make a statement without teasing about the hearer.

@mtho_madlala

(4 weeks ago, 39 likes, 3 replies)
I would give my life to be part of this discussion (PP/5)

The speaker supports the hearer's activity by saying his expectation. He says that he wants to gather with the group discussion visited by Bill Gates. He viewed Bill 'activity as interesting and useful. At this moment, By expressing his expectation, the speaker creates a better impression and makes the imposition less inappropriate. So, it belongs to the strategy of exaggerating interest or approval.

\section{@ kalamartin123 \\ (4 weeks ago) \\ Being open and honest. We are the same. (PP/38)}

The speaker makes a small talk that includes the hearer into the chat. He uses the pronoun "we" to include the hearer showing that the speaker believes that Bill and he have the same character. Therefore, the speaker can eliminate the threat when he or she asks Bill to go and complain. The utterance shows that the speaker used the strategy of presupposing, raising, asserting common ground.

\section{@arthurgrin84}

(4 weeks ago, 1 like)

You are a true visionary, an exemplary philanthropist. Thanks for the inspiration always (PP/23)

He supports him thoroughly with his response. He gives his compliment to add a statement that can raise Bill Gates' statement. He also gives an expression of thanking to what that Bill is doing. Without the hearer asks him, he tries to satisfy Gates' positive face. The utterance refers to the strategy of noticing, attending to the hearer's interest, wants, or needs.

Women's comments

\section{@kiaabiaa}

(3 weeks ago, 23 likes, 5 replies)

I admire your love for humanity; you have sewn into my life and lead me places where I would have never been able to go if I wasn't a Gates Scholar. I am so grateful and fulfilled. (PP/7)

The speaker's comment shows that she is delighted and proud to become part of Gates Scholar. The speaker indicates her exaggeration by saying that one of the crucial people in her life is Bill Gates. This utterance uses the strategy of exaggerating interest or approval with the hearer.

@ red_heels 217

(4 weeks ago, 7 likes) 


\section{LingTera,6 (1), 2019 - 77}

\section{Arini Dwi Sholikhatin, Rohmani Nur Indah}

If everyone reached out to the young, they would see many folks have their tragedies, yet most are respectful. Not everyone is evil like others think; these teens are typical great teens. (PP/18)

She supports him thoroughly with her response that can raise Bill Gates' statement. Without the hearer asks her, she tries to satisfy Gates' positive face. It shows that the speaker used the strategy of presupposing, raising, and asserting common ground.

@ cindy6262.m

(3 weeks ago)

Good on you, Bill!! (PP/29)

She employs positive politeness by using in-group identity marker. The identity marker is "Bill" as a familiar nickname. She uses this word to minimise the threat as she gives support to the hearer. Moreover, the hearer's positive face is saved because he has been treated in the same group. So, the utterance shows that she used is the strategy of using in-group identity markers.

@bening.wahyu

(3 weeks ago)

Agree. And I love the way you dedicate your time to continuously meaningful for others... @ thisisbillgates dream to be able to see you in person and to inspire teenage here... (PP/33)

Bill Gates tells about the teenage boy's group discussion sharing their problems and experiences. Then, she tries to safe Gates' positive face by seeking an agreement from Bill's statement. She expresses her agreement by saying, "Agree." By saying this agreement, she shows her cooperation with him. Then, the utterance uses the strategy of seeking an agreement that showed by her comment.

@henrietta_reese

(4 weeks ago)

Was there another discussion with girls only? I mean there was probably a reason for it. So I think it's important to start with gender equality at the very source. $(P P / 35)$

She is hiding her disagreement to save Gates' positive face. She chooses to say, "I mean...I think..." Therefore she makes the hearer feel good because the hearer thinks that his opinion is not wrong. It indicates that the utterance shows that the speaker used the strategy of avoiding disagreement.

@fotolishma:

(3 weeks ago)

Yeah, children who experience trauma struggle. Adolescence for the most sheltered is tough, I know. Kids who lived through difficult circumstances so early are straddled with even more to deal with. You are helping by understanding their pain. Good work! (PP/32)

In this datum, tye speaker shares some common purposes with the hearer. It is done by increasing the hearer's interest, which may pull the attention to the chat. Before the speaker tells the story, it starts by saying, "Yeah....." This phrase makes the hearer interested in listening to his or her story.

It shows that the speaker has saved the hearer's positive face making him involved in the chat. Then, he feels satisfied since he has been accepted and treated as a group member. It indicates that the speaker used the strategy of intensifying interest to the hearer in the speaker's contribution.

\section{@livingmalibu}

\section{(4 weeks ago, 4 likes)}

By your actions and empathy, you and Melinda are a much needed and marvellous example to those that have power or the means to make a difference in our world. While it is true that each of us can make a difference, your example will hopefully shift resources towards addressing our most challenging issues. Thank you for shining the light. $(P P / 20)$

The speaker shows his or her solidarity as she knows personal information about him. By fulfilling the hearer's wants, she can save the hearer's positive face. This sentence shows the cooperation stressed. She indicates the personal information about Bill Gates.

The speaker gives information about Melinda too, who is Bill's wife. She knows about them. Thus, the hearer's positive face has been satisfied through the speaker's acceptance. So, this utterance shows that she used the strategy of asserting or presupposing knowledge of and concerning for hearer's want.

Positive Politeness of Comments Column in Bill Gates' Instagram

The findings show that from fifteen strategies of positive politeness, ten strategies are often used by the Instagram user to comments Bill Gates' caption on February, 22nd 2019.

The first strategy is noticing, attending to the hearer's interests, wants, needs, goods, etc. Thirteen data show the utterance that includes this strategy. The concept of this strategy is that the speaker could satisfy the hearer's positive face by noticing hearer's interest, wants, or needs. The 


\section{LingTera,6 (1), 2019 - 78}

\section{Arini Dwi Sholikhatin, Rohmani Nur Indah}

example of this strategy is shown in Datum 23, which explains that the speaker supports Gates thoroughly. He gives his compliment to add a statement that can raise Bill Gates' statement. Moreover, he gives an expression of thanking for what Bill has done. Without the hearer asks him, he tries to satisfy Gates' positive face.

The second strategy is exaggerating interest, approval, or sympathy with the hearer. This strategy can be done by making something seem vital than it is. The speaker uses this strategy to emphasise his feelings toward the hearer, which may include interest or approval. The findings show nine strategy. For an example of this strategy is in Datum 5, where the speaker supports the hearer's activity by saying his expectation. He says that he wants to gather with the group discussion visited by Bill Gates. It shows that he wants together with the hearer. He viewed Bill 'activity is interest and useful. At this moment, the speakers express in the form of expectation to create a good impression and make the imposition less inappropriate.

The third strategy is using in-group identity markers in speech. The speaker can show solidarity and intimacy with the hearer by using familiar call names. These identity markers strengthen the closeness between them. The findings show five data that indicate utterances that used this strategy. The example of this strategy is indicated by Datum 29, in which the speaker used the nickname Bill to minimise the threat as the speaker is giving support to the hearer. Moreover, the hearer's positive face is saved because he has been treated as a member of the same group. So, the utterance shows that she used the strategy of using in-group identity markers.

The fourth strategy is presupposing, raising, or asserting common ground. This strategy can be done by sharing the same interests as others. The speaker can make a small talk that includes the hearer into the chat. This strategy often appears too in the findings. Four data show this strategy. The examples of this strategy are in Datum 38 explaining about the speaker that tells about how Gates has the same character with him. It shows that the speaker used the strategy of presupposing, raising, and asserting common ground.

The fifth strategy is seeking agreement on safe topics. It means that this strategy allows the speaker to find a possibility, in which he can agree with the hearer's statement in safe topics. In the findings, three data show about this strategy.
The example of this strategy is showing by Datum 24. The datum shows that the hearer tells about the teenage boy's group discussion sharing their problems and experiences. Then, the speaker tries to save the hearer's positive face by seeking an agreement from the hearer's statement. The speaker expresses his agreements indicating that the utterance uses the strategy of seeking agreement.

The last strategy is intensifying interest to the hearer in the speaker's contribution. The concept of this strategy is the speaker shows that he shares some common purposes. It can be done by making an excellent expression to start with. Two data indicates this strategy, for example, is Datum 32. The Datum shows that the speaker tries to get the Gates' attention by saying a word, which makes him interested in the topic. It shows that the speaker has saved the hearer's positive face because the speaker has made the hearer involved in the discussion.

Another strategy like avoiding disagreement, joking about putting the hearer at ease, asserting or presupposing knowledge of and concerning for hearer's want, and offering, promising is just once appeared in the findings. In conclusion, there are ten strategies from fifteen strategies of positive politeness that is used by men and women to give comments in Bill Gates' Instagram account.

\section{Discussion}

The finding showed twenty men given positive politeness to respond to Bill Gates' captions on Instagram. There are seven types of the strategy of positive politeness that found in men comments. The dominant strategy used by men is noticing, attending to the hearer (his/her interests, wants, needs, goods) and exaggerating (interest, approval, sympathy with hearer).

As the first strategy is noticing, attending to the hearer (his interest, wants, needs, goods). Based on the data analysis above, eight utterances of men appropriate with this strategy, among them are data $2,6,15,16,22,23,30$, and 34 . The fulfilment of the first strategy is directed to achieve the notice of the speaker to the hearer. Hence, the hearer' positive face is fulfilled as the speaker has paid attention.

The second strategy is exaggerating (interest, approval, sympathy with the hearer). Based on the data analysis above, six utterances of men appropriate with this strategy, covering data $1,4,5,11,27$, and 36 . The fulfilment of this strategy is often conducted with exaggerating 


\section{LingTera,6 (1), 2019 - 79}

\section{Arini Dwi Sholikhatin, Rohmani Nur Indah}

interest or sympathy by the speaker. Hence, the hearer's positive face is fulfilled because it shows that the speaker is interested.

The next strategy is using in-group identity markers. There is one utterance of men that fit with it, Datum 31. The fulfilment of this strategy uses address form, such as the nickname Bill. It can be used to show intimacy between the participants.

Another strategy employed is seeking agreement shown in Data 24 and 40 in which the speaker directs the hearer to decide to take action by the addressee. It also shows that the speaker pays attention to the hearer. Hence, the hearer's positive face is fulfilled because the speaker has appreciated him.

Based on the data analysis above, there is one utterance of men that appropriate with the strategy of presupposing/raising/asserting a

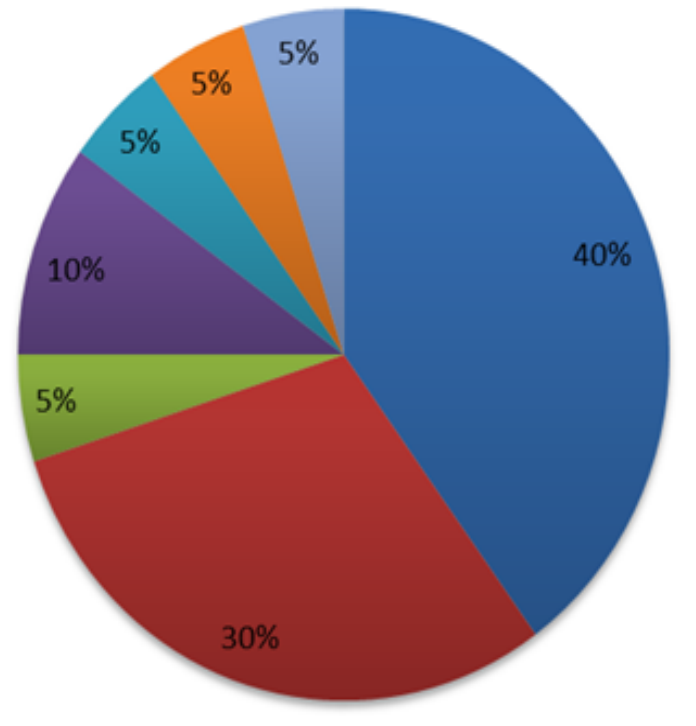

common ground. It is found in Datum 38. The fulfillment of this strategy is required when the speaker speaks to the hearer as if it will be mutually assumed.

The strategy of joking is found in one utterance of men. It is found in Datum 3. The fulfilment of this strategy is required when the speaker saves the hearer's face through a joke so that the hearer is not embarrassed because he can hide it.

The last strategy is offering or promising. Based on the data analysis above, there is one utterance of men that appropriate with strategy 10. It is found in Datum 25. The fulfilment of this strategy is required when the speaker emphasized on his cooperation with the hearer in another way. Whatever the hearer's wants, he wanted to fulfil for the hearer.

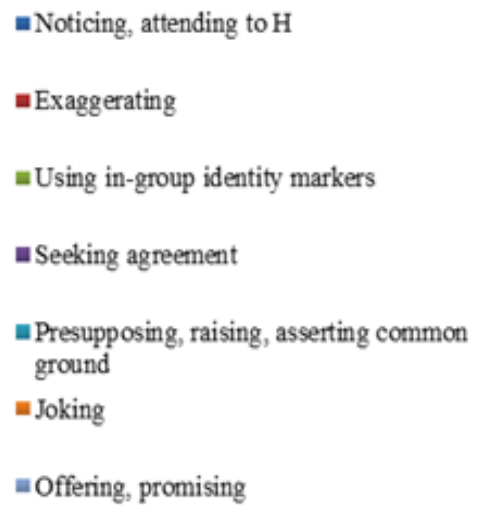

Figure 2. Men's Politeness Strategies

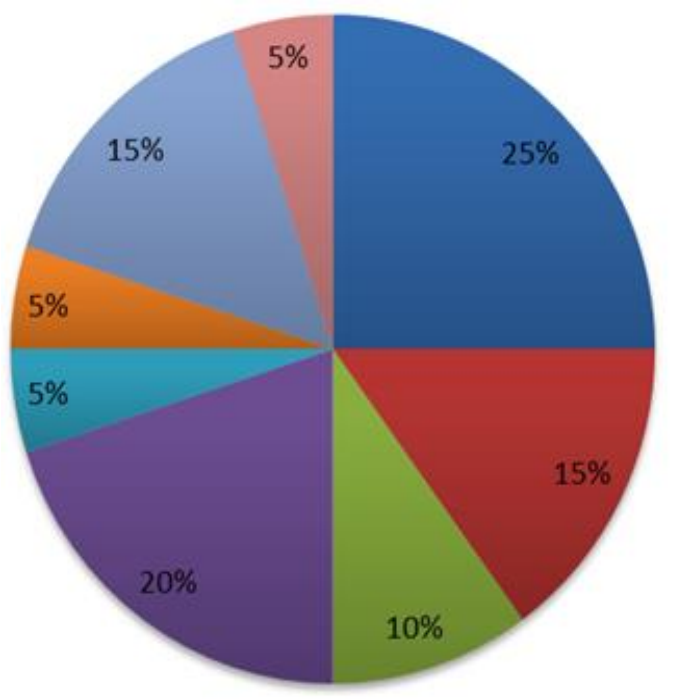

Figure 3. Women's Politeness Strategies 


\section{LingTera, 6 (1), 2019 - 80}

\section{Arini Dwi Sholikhatin, Rohmani Nur Indah}

Women Comments of Responding to Bill Gates' Caption on Instagram

The finding shows there are twenty women those given positive politeness to respond to Bill Gates' captions on Instagram. They use some of the strategies of positive politeness. There are eight types of the strategy of positive politeness that found in women comments. The dominant strategy used by women is noticing, attending to the hearer (his/her interests, wants, needs, goods) and using in-group identity markers.

As the first strategy is noticing, attending to the hearer (his interest, wants, needs, goods). Based on the data analysis above, there are five utterances of women appropriate with strategy 1 among them are Data 5, 13, 14, 17, and 21. This strategy is indicating the notice of the speaker to the hearer and approve the hearer's condition. Hence, the hearer' positive face is fulfilled by obtaining attention.

The second strategy is exaggerating (interest, approval, sympathy with the hearer). Based on the data analysis in Figure 2, there are three utterances of women that appropriate with strategy 2. They found in Data 7, 12, and 37. This strategy is often conducted with exaggerating interest or sympathy. Hence, the hearer's positive face is fulfilled because it shows that the speaker was interested in the topic.

The next strategy is using in-group identity markers. There are four utterances of women that fit with strategy 4 among them are data 10, 28, 29 , and 39. The fulfilment of this strategy uses address form, such as baby (Datum 10), Bill (data 28,29 ), gentleman (Datum 29). It can be used to show intimacy between the participants.

Another strategy employed is seeking agreement shown in Datum 33. It is indicated by the speaker directs the hearer to take action by the addressee. Besides, it also shows that the speaker pays attention to the hearer. Thus, it identifies how the hearer's positive face is fulfilled.

Women also employ the strategy of avoiding disagreement. It is found in Datum 35. The fulfilment of this strategy is used to avoid disagreement to satisfy the hearer so that she/he feels approved. It could be done by, pseudo agreement.

Based on the data analysis above, there are three utterances of women that appropriate with the strategy of presupposing or raising/asserting a common ground. They are found in Data 9, 18, and 26. The fulfilment of this strategy is required when the speaker speaks to the hearer as if it will be mutually assumed.

The strategy of asserting the speaker's knowledge and concern for the hearer's desire is found in Datum 20. The fulfilment of this strategy is required when the speaker knows the hearer's wants. Besides, the speaker paid attention to the hearer so that he cooperated with the speaker. Again, the hearer's positive face is fulfilled through the implementation of this strategy.

Thus, there are five types of positive politeness strategy that similarly used by both men and women. They are strategy of noticing, attending to the hearer (his interests, wants, needs, goods), the strategy of exaggerating (interest, approval, and sympathy with hearer), the strategy of using in-group identity markers, the strategy of seeking agreement, and strategy of presupposing, raising, asserting common ground. Thus, there are five strategies not found in data analysis. They are the strategy of being optimistic, the strategy of including both speaker and hearer in the activity, the strategy of giving or asking for reasons, the strategy of assuming or asserting reciprocity, and strategy of giving gifts to the hearer (goods, sympathy, understanding, cooperation).

Gender difference, as shown in this study, uncovers the fact that women users in Instagram tend to use more various positive politeness strategies compared to men. It supports the finding that man and woman tend to use different strategies of positive politeness in a talk show (Safitri, 2015). It is also in line with another finding that female users in Instagram tend to use more emotional and positive hashtag description compared to male users (Ye, Hashim, Baghirov, \& Murphy, 2018). In this case, it displays a dissimilar fact compared to negative politeness. Regarding impoliteness in Instagram comments, there is no significant difference in the use of sarcasm or mock politeness by male and female haters (Apriliyani, Hamzah, \& Wahyuni, 2019).

\section{CONCLUSION}

Among the positive politeness strategies in the data, the most dominant type used by Instagram users in responding to Bill Gates' caption on Instagram is noticing, attending to the hearer's interests, wants, or needs. Similarly, the comments from men dominantly employed positive politeness with the strategy of noticing, attending to the hearer's interests, wants, or needs. There are two strategies only found in the comments by men. They are the strategy of 


\section{LingTera,6 (1), 2019 - 81}

Arini Dwi Sholikhatin, Rohmani Nur Indah

joking about putting the hearer at ease and strategy of offering, promising. Whereas, the dominant positive politeness strategy used by women are noticing, attending to the hearer's interests, wants, or needs, goods. Also, women used some strategies that not found in men's comments. They are the strategy of intensifying interest to the hearer, strategy of avoiding disagreement, and strategy of asserting or presupposing speaker's knowledge of concern for hearer's wants.

While studies show that there is no gender difference in the use of impoliteness, this study found that gender difference exists in the use of positive politeness in social media, particularly on Instagram. Therefore, further studies are suggested to find the pattern of positive politeness in other contexts, such as in a comic, television show, Facebook, movie, direct conversation, etc. Furthermore, this research hopefully becomes a reference for positive politeness for those interested pragmatics, as well as for EFL teachers and students. By exploring the phenomenon on the use of positive politeness, it is expected that EFL learners can cultivate their practical skill for achieving better communicative competence.

\section{REFERENCES}

Ammaida, Y., \& Muttaqien, M. Z. (2018). Politeness strategies of the comments toward international women" $s$ day ( $A$ pragmatic case study on Donald Trump" $s$ Instagram post). IAIN Surakarta.

Anggriani, D. (2016). Impoliteness used by haters in celebrities Instagram. Universitas Negeri Medan.

Apriliyani, V., Hamzah, H., \& Wahyuni, D. (2019). Impoliteness strategies used by male and female haters of Habib Rizieq and Felix Siauw found in Instagram comments. E-Journal English Language and Literature, 8(1), 158-167. Retrieved from

http://ejournal.unp.ac.id/index.php/ell/arti cle/view/103213

Ariputra, A. M., Rohmadi, M., \& Sumarwati, S. (2018). Language politeness principle in Indonesia lawyers club talkshow on TV One. OKARA: Jurnal Bahasa Dan Sastra, 12(1), 115-124. https://doi.org/http://dx.doi.org/10.19105/ ojbs.v12i1.1766

Bossetta, M. (2018). The digital architectures of social media: Comparing political campaigning on Facebook, Twitter, Instagram, and Snapchat in the 2016 US election. Journalism \& Mass Communication Quarterly, 95(2), 471496.

https://doi.org/https://doi.org/10.1177/107 7699018763307

Brown, P., Levinson, S. C., \& Levinson, S. C. (1987). Politeness: Some universals in language usage. Cambridge University Press.

De Felice, R., \& Garretson, G. (2018). Politeness at work in the Clinton email corpus: A first look at the effects of status and gender. Corpus Pragmatics, 2(3), 221-242. https://doi.org/https://doi.org/10.1007/s41 701-018-0034-2

Duhita, A. A., \& Zulaeha, I. (2018). The politeness speech of primary school teacher in the character building of learners. Seloka: Jurnal Pendidikan Bahasa Dan Sastra Indonesia, 7(2), 112121. Retrieved from https://journal.unnes.ac.id/sju/index.php/s eloka/article/view/25182

Fajaruddin, S. (2011). Analisis prinsip kerja sama Grice dalam naskah drama Dr. med.hiob. Prätorius karya Kurt Goetz. Fakultas Bahasa dan Seni Universitas Negeri Yogyakarta, Yogyakarta.

Gay, L. R., Mills, G. E., \& Airasian, P. W. (2011). Educational research: Competencies for analysis and applications. Pearson Higher Ed.

Gharaghani, Z., Eslami Rasekh, A., Dabaghi, A., \& Tohidian, I. (2011). Effect of gender on politeness strategies in greetings of native speakers of Persian; English and EFL learners. Cypriot Journal of Educational Sciences, 3, 93-117.

Harooni, M., \& Pourdana, N. (2017). Politeness and indirect request speech acts: Genderoriented listening comprehension in Asian EFL context. International Journal of Applied Linguistics and English Literature, 6(2), 214-220. https://doi.org/http://dx.doi.org/10.7575/ai ac.ijalel.v.6n.2p.214

Horn, L., \& Kecskés, I. (2013). Pragmatics, discourse, and cognition. In The Language-Cognition Interface (pp. 355375). Geneva-Paris: Librairie Droz. 


\section{LingTera,6 (1), 2019 - 82}

\section{Arini Dwi Sholikhatin, Rohmani Nur Indah}

Indrawan, F. (2018). Impoliteness strategy in Instagram cyberbullying: A case study of Jennifer Dunn posted by@ Lambe_Turah. Etnolingual, 2(1). https://doi.org/http://dx.doi.org/10.20473/ etno.v2i1.8440

Jauhari, A. (2017). Realisasi kesantunan berbahasa dalam proses belajar mengajar Bahasa Indonesia kelas XI SMK. LingTera, 4(2), 112-121. https://doi.org/10.21831/lt.v4i2.10056

Kamlasi, I. (2017). The positive politeness in conversations performed by the students of English study program of Timor University. Metathesis, 1(2). https://doi.org/10.31002/metathesis.v1i2.4 67

Kurdghelashvili, T. (2015). Speech acts and politeness strategies in an EFL classroom in Georgia. International Scholarly and Scientific Research \& Innovation, 9(1), 306-309.

Matley, D. (2018). "This is NOT a \#humblebrag, this is just a \#brag": The pragmatics of self-praise, hashtags and politeness in Instagram posts. Discourse, Context \& Media, 22, 30-38. https://doi.org/10.1016/j.dcm.2017.07.007

Mey, J. L. (2001). 40 literary pragmatics. In The Handbook of Discourse Analysis (p. 787).
Paltridge, B. (2012). Discourse analysis: An introduction. Bloomsbury Publishing.

Pradnyani, N. L. P. B., Budiarsa, M., \& Sudana, I. G. P. (2017). Positive politeness strategies in animation movie "Home" directed by Tim Johnson. Humanis: Journal of Arts and Humanities, 19(1). Retrieved from https://ojs.unud.ac.id/index.php/sastra/arti cle/view/29661

Safitri, D. (2015). The positive politeness strategies used by Jimmy Kimmel live talk show with Selena Gomez as guest star. UIN Sunan Ampel Surabaya.

Saragih, W. (2016). The acquisition of communicative competence as one important aspect of culture: How should communicative competence be built? Bahas, 27(2). https://doi.org/https://doi.org/10.24114/bh s.v27i2.5633

Ye, Z., Hashim, N. H., Baghirov, F., \& Murphy, J. (2018). Gender differences in Instagram hashtag use. Journal of Hospitality Marketing \& Management, 27(4), 386404.

https://doi.org/10.1080/19368623.2018.13 82415 